\title{
Pyrolysis and incineration in polymer waste management system
}

Jolanta WRÓBLEWSKA-KREPSZTUL, Tomasz RYDZKOWSKI

DOI: 10.30464/jmee.2019.3.4.337

Cite this article as:

Wróblewska-Krepsztul J., Rydzkowski T. Pyrolysis and incineration in polymer waste management system. Journal of Mechanical and Energy Engineering, Vol. 3(43), No. 4, 2019, pp. 337-342.

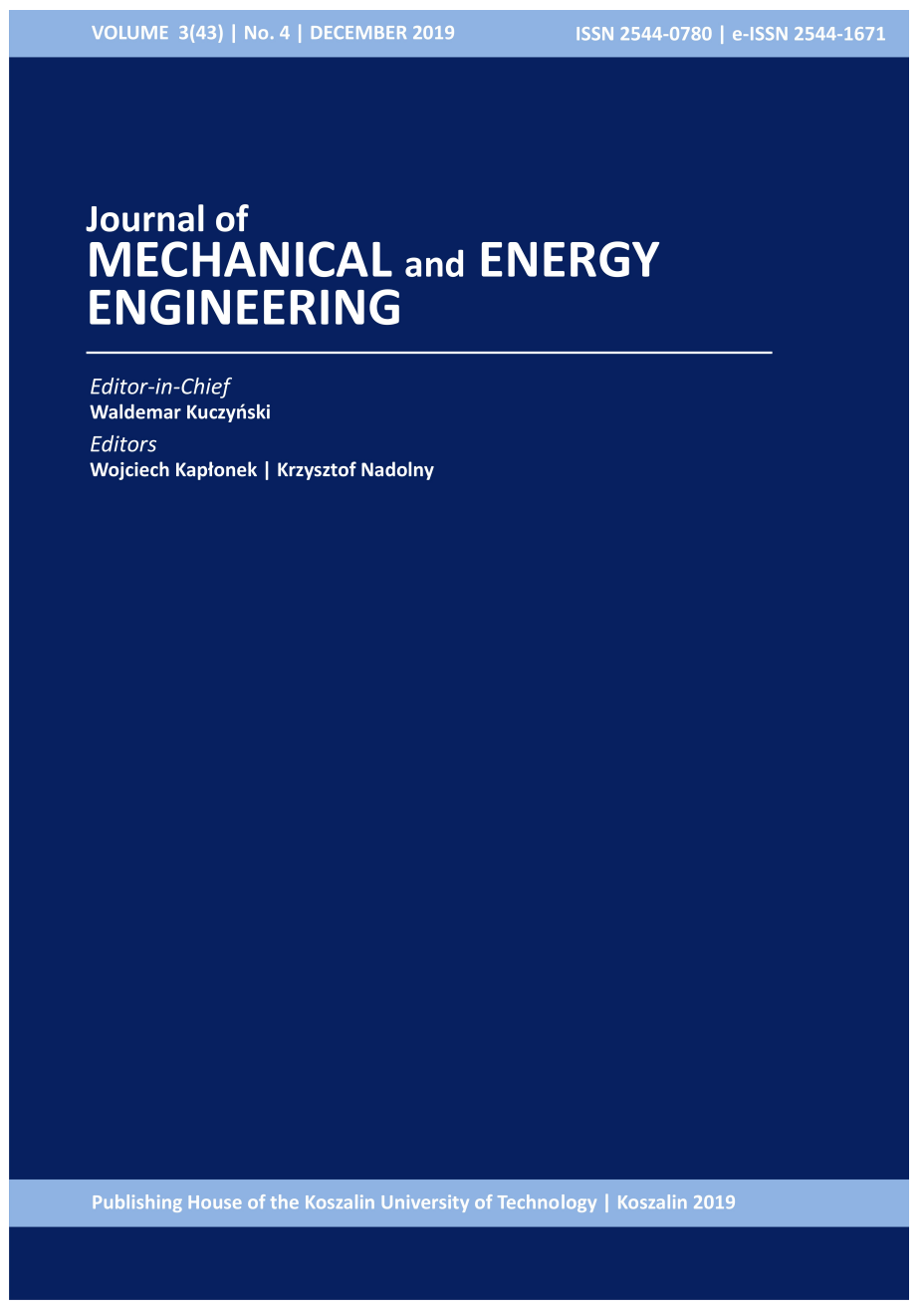

Journal of Mechanical and Energy Engineering

Website: jmee.tu.koszalin.pl

ISSN (Print): 2544-0780

ISSN (Online): $2544-1671$

Volume: $3(43)$

Number: 4

Year: 2019

Pages: $337-342$

Article Info:

Received 31 January 2020

Accepted 10 February 2020

\section{Open Access}

This article is distributed under the terms of the Creative Commons Attribution 4.0 (CC BY 4.0) International License (http://creativecommons.org/licenses/by/4.0/), which permits unrestricted use, distribution, and reproduction in any medium, provided you give appropriate credit to the original author(s) and the source, provide a link to the Creative Commons license, and indicate if changes were made. 


\title{
PYROLYSIS AND INCINERATION IN POLYMER WASTE MANAGEMENT SYSTEM
}

\author{
Jolanta WRÓBLEWSKA-KREPSZTUL ${ }^{1}$, Tomasz RYDZKOWSKI ${ }^{1}$ \\ 1 Politechnika Koszalińska, Wydział Mechaniczny, Katedra Procesów i Urządzeń Przemysłu Spożywczego, \\ Racławicka 15-17, 75-620 Koszalin, e-mail: tomasz.rydzkowski@tu.koszalin.pl, \\ jolanta.wroblewska-krepsztul@s.tu.koszalin.pl
}

(Received 31 January 2020, Accepted 10 February 2020)

\begin{abstract}
Waste and associated risks are becoming an increasingly noticeable problem in environmental protection in our time. The management of especially industrial waste is a difficult and at the same time a significant problem. Incineration is the basic process of thermal utilization. The combustion process is not neutral for the environment, and is associated with the emission of dust, sulfur and nitrogen compounds as well as dioxins and furans. Therefore, combustion installations must be equipped with a number of devices for cleaning the exhaust gases. The most primary process of obtaining useful energy from biomass, i.e. combustion, is characterized by specific dynamics. Regardless of the technique, it is affected by physical and chemical processes. The condition of economic and technical correctness of co-firing is maintaining the optimal share of biomass in the fuel mixture and its appropriate quality. Effective co-firing of the prepared mixture can be carried out in existing grate, fluid and dust boilers. Pyrolysis is a stage in both the combustion and gasification process. In this process, as a result of the thermal decomposition of the structure of the organic fuel, we obtain carbonizate as well as tar and gas products. In the pyrolysis process, solid fuel is transformed into two other forms: gaseous fuel and liquid fuel. The share of individual forms and their composition depends on the type and composition of biomass, as well as the method of conducting the pyrolysis process. In highly developed countries, works are ongoing to improve and increase the efficiency of biomass combustion processes and co-firing of biomass with coal, also in circuits with a syngas gas turbine. In addition to the development of technology, great emphasis is also placed on the search for new methods of biomass processing, as well as methods of processing polymeric materials, which until now have caused difficulties in processing.
\end{abstract}

Keywords: energy waste, pyrolysis, polymer waste, recycling

\section{INTRODUCTION}

In the world in the face of global challenges, a rapidly growing population, one should look for efficient solutions that at the same time guarantee the sustainable development of plastic materials. Their versatility and high efficiency of using their resources means that they are important materials in many sectors such as packaging. The use of plastics allows the introduction of many innovations and the creation of new solutions and products. The durability of plastics means that they are efficient in use but at the end of their shelf life they become waste, which can be a new resource reintroduced into the life cycle of plastics and form a loop of a closed circular economy. The use of the full potential of plastics should be supported by recycling and the use of energy recovery, reducing the growth of plastic waste landfills Fig. 1, 2. This applies to difficult in processing polymers, polymeric materials and polymer composites especially contaminated with additional substances [1].

In the world 335 million tons of plastic were produced in 2016. In the same year, 60 million tons of plastic were produced in Europe. In 2016, more than 8.4 million tonnes of plastic waste were collected to be recycled inside or outside the EU The most popular plastics are still: polyethylene terephthalate (PET), polyethylene (PE), polypropylene (PP), polystyrene (PS) and polyvinyl chloride (PVC). The durability of plastics is the same, which causes a negative impact on the environment, i.e. the deposition of materials in the environment $[2,3]$. 


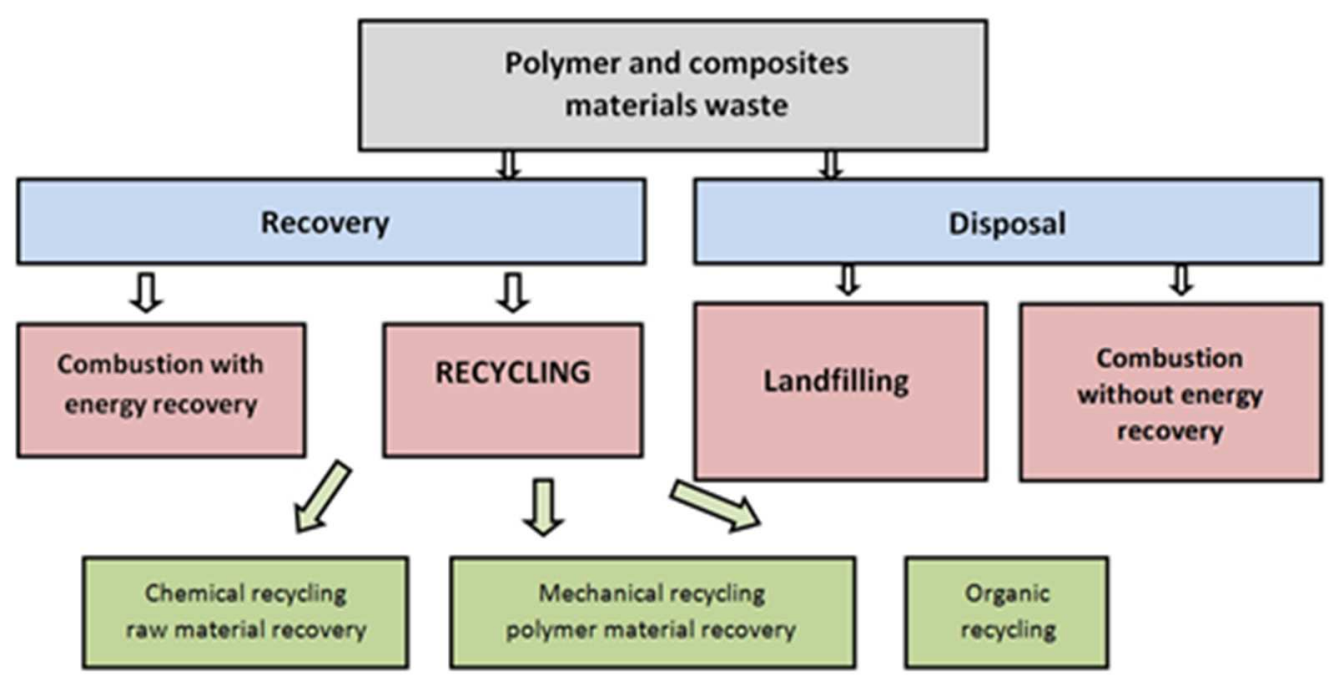

Fig. 1. Classification of waste management methods for polymer and composites materials waste

\section{ENERGETIC LIFE CYCLE OF PLASTICS}

Plastics are a group of materials containing structured macromolecular compound as a dominant element. Other components of this material are usually additives that modify the properties of the final material, i.e. dyes, stabilizers, flame retardants, foaming agents or fillers. Currently, several dozen groups of materials are known, but the category of large volumes (mass produced) includes: polyethylene (PE) sometimes differentiated into low density (LDPE) and high density (HDPE), polypropylene (PP), polyvinyl chloride (PVC), polystyrene (PS) and polyethylene terephthalate (PET). They all belong to the group of thermoplastics. The share of other polymeric materials does not exceed $20 \%$ by weight $[4,5,6,7]$.

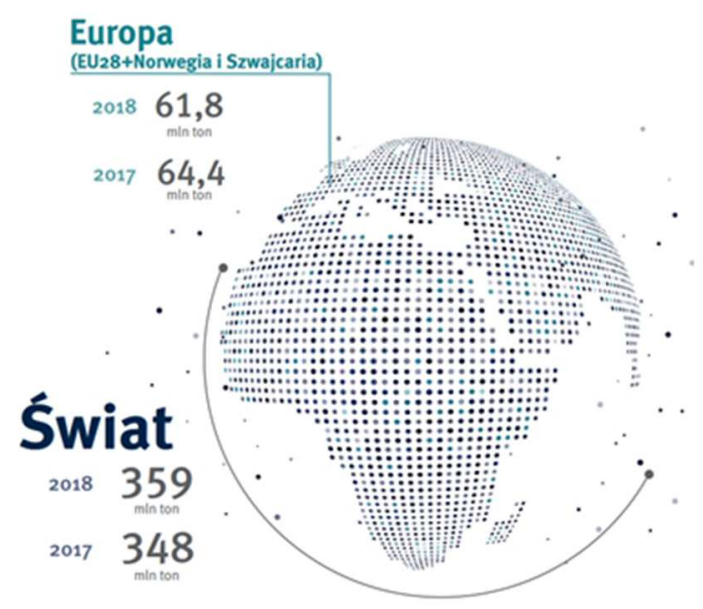

Fig. 2. Plastic waste production in recent years [8]. Source: Reprinted with PlasticsEurope permission
Initially, two main raw materials for the production of bakelite: formaldehyde and phenol, were obtained as a result of dry distillation of wood and coal tar [9].

Energy recovery is a necessary, fully-fledged method of managing plastic waste, complementing recycling, enabling full utilization of the potential of waste for energy and heat production. Recycling is not an ecologically and economically viable recovery method for all plastics, as many factors affect the recyclability $[2,3]$ :

- the size and quality (homogeneity, purity, toxicity) of the waste stream collected in selective collection,

- available sorting technologies,

- market demand for products recovered from plastic waste and requirements for their quality.

Therefore, for high-calorie waste fractions from sorting and recycling that cannot be recycled, the best option is energy recovery - compared to landfilling or forced recycling. Modern installations for the combined production of heat and electricity can use plastic waste along with other high-calorie materials as fuel. High-calorie waste is a valuable source of energy and heat, which can meet up to $10 \%$ of the energy demand of a given EU country. Solid Fuels from Waste (SRF), which waste plastic is a valuable fraction, are increasingly used for energy production as well as in energy-intensive industries such as cement plants, replacing fossil raw materials. The management of plastic waste in recent years is evident in Fig. 3.

All waste energy recovery installations meet stringent environmental requirements, they are efficient and secure [10, 11]. 

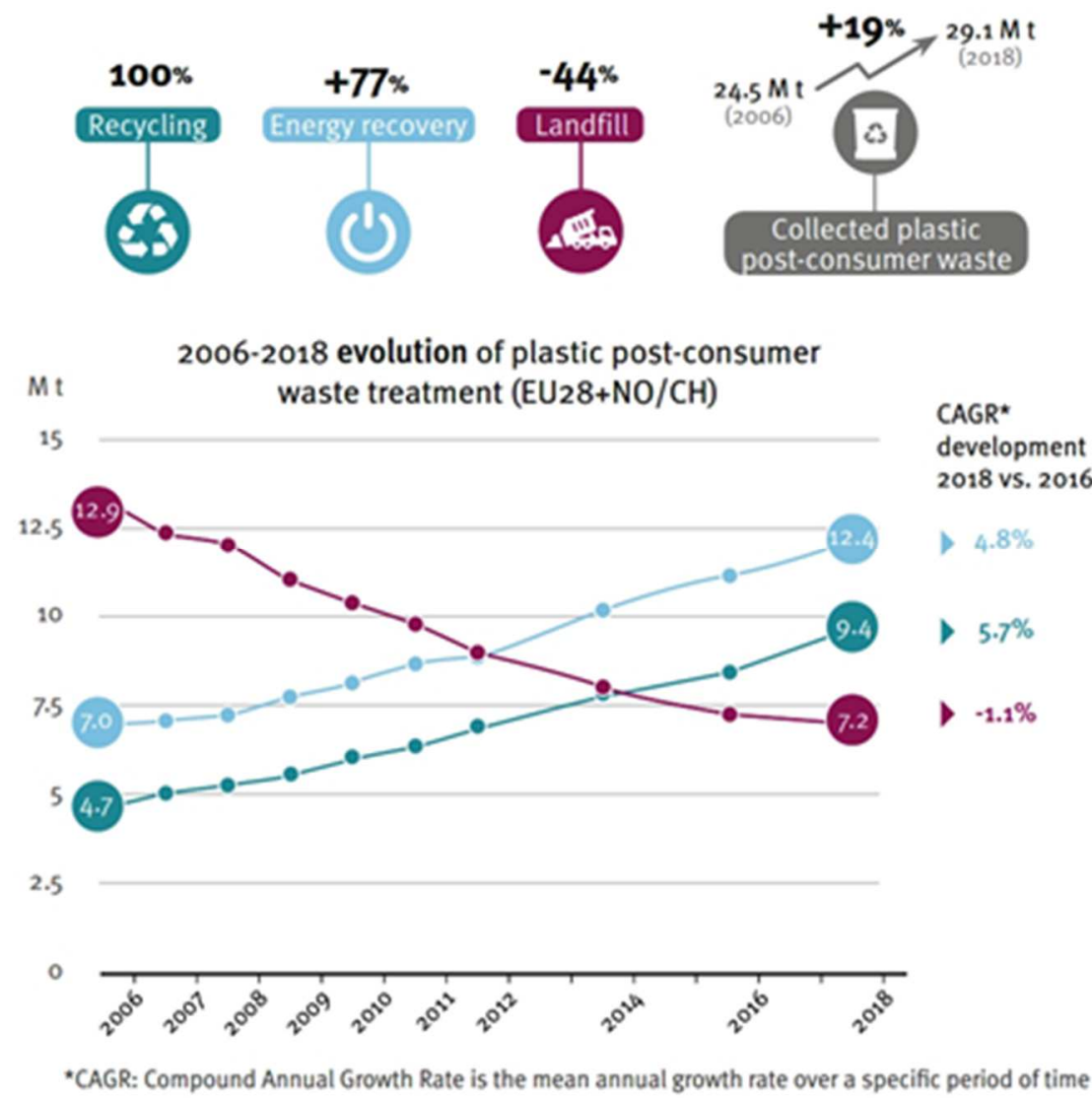

Fig. 3. Management of plastic waste [8]. Source: Reprinted with PlasticsEurope permission

\section{ENERGY RECOVERY}

The process of pyrolysis of artificial waste arouses great interest in the world of science due to the possibility of obtaining liquid fuel in the presence of exhaustible liquid fossil fuel [12]. Studies have shown that $80 \mathrm{wt} \%$ of liquid yield can be achieved in the pyrolysis process. Energy recovery is seen as an alternative to sustainable waste management - Fig. 4. The important parameters of the pyrolysis process were also examined, such as: temperture, the plasticity ratio of the components, the type of the fluidization gas deposit $[13,14,15,16]$.

The recovery and utilization of refuse to generate energy using appropriate technology is very expensive for the industry. Food chain waste includes food, beverage and food waste. According to the European Sustainable Development Strategy, waste is expected to be reduced through re-use. Food waste is estimated at 1.6 billion tonnes per year of all food produced [17].

Pyrolysis is a process of thermochemical conversion of biomass in an anaerobic environment and is used for the production of coal, biofuels, solid gases and the water phase (process water). We divide the pyrolysis into three main types: slow, intermediate and fast, different in terms of temperature, heating speed and vapor residence times [18].

Fast pyrolysis takes place at a temperature below $500^{\circ} \mathrm{C}$, whereas indirect pyrolysis uses a lower temperature range of $350-450^{\circ} \mathrm{C}$. Recently, interest in the rapid pyrolysis process has increased particularly because it provides economic benefits compared to other thermal conversion processes [19]. Rapid pyrolysis is the latest process associated with renewable energy, during which you can get a bio-oil suitable for easy storage and transport and it is used as a fuel, energy carrier, source of chemical materials [20]. It has been determined that pyrolysis oil consists of about 300-400 compounds and its aging process dependent on high temperature can be compensated by storing the product at lower temperatures. The quality and stability of the product can be changed by the influence of parameters such as: heating speed, pyrolysis temperature [21]. Fast pyrolysis is an advanced process that can be controlled to achieve high liquid performances. It is a high-temperature process during which the raw material warms up in the absence of air, evaporates and condenses to a dark brown liquid whose heating value is half of the value of conventional fuel oil. 


\section{Plastics waste is a key resource in the move towards circular economy}

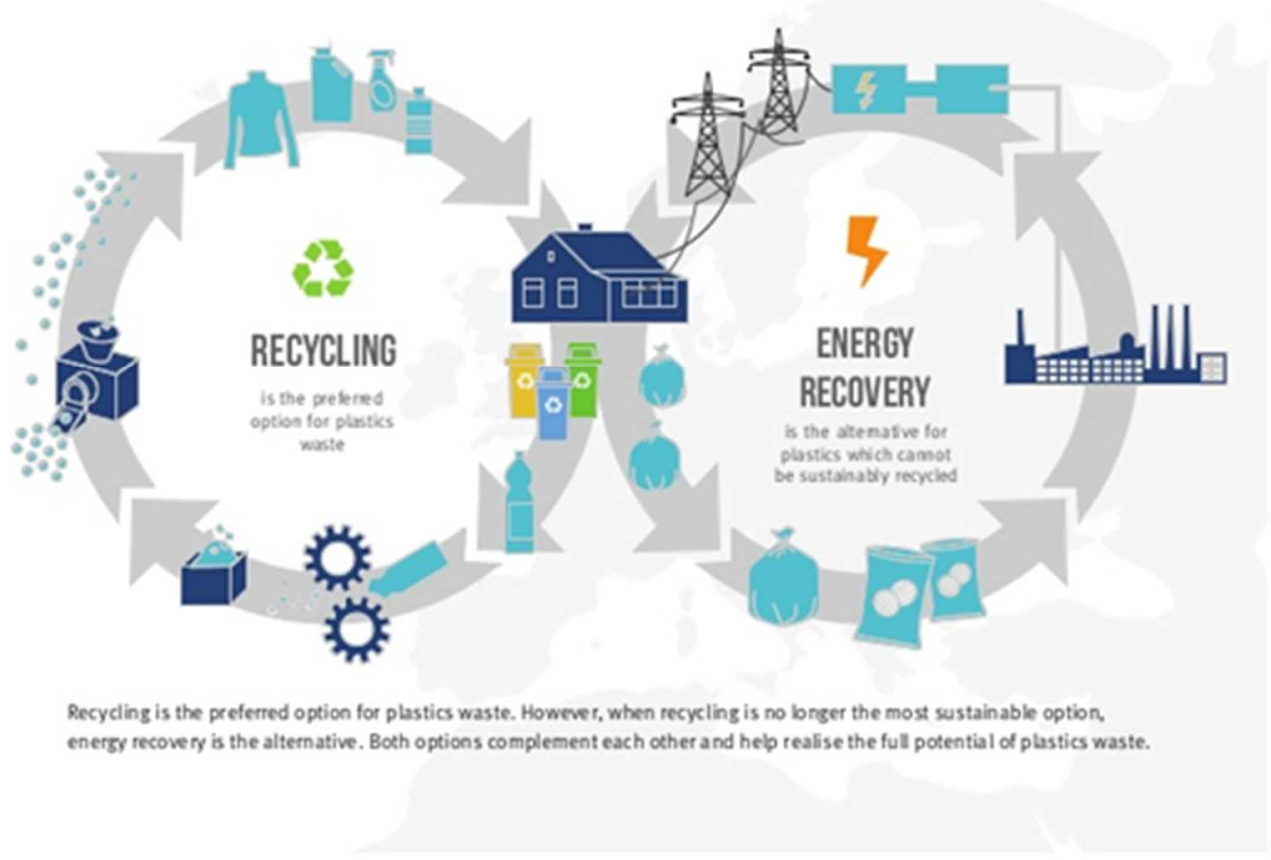

Fig. 4. Energy recovery as an alternative to sustainable waste management of plastics [8] Source: Reprinted with PlasticsEurope permission

It has been observed that the maximum liquid efficiency is obtained when the heating speed is high, at a temperature of about $5000^{\circ} \mathrm{C}$ during a short time to minimize secondary reactions as much as possible. Bio-oil is obtained with a yield of $75 \mathrm{wt} . \%$ on a dryfeed basis. A by-product and gas are also obtained [22]. The pyrolytic process of thermal decomposition leads to three products: solid, liquid and gas bodies. In the process of biomass decomposition oil and tar are formed, i.e. mixtures of hydrocarbons, phenols and about 200 different organic compounds (aliphatic, aromatic, saturated and unsaturated). The gas fraction is a mixture of $\mathrm{CO}, \mathrm{CO}_{2}, \mathrm{H}_{2}$, hydrocarbon gas $\left(\mathrm{CH}_{4}\right.$, $\mathrm{C}_{2} \mathrm{H}_{6}$ ), calorific value steam is about $12 \mathrm{MJ} / \mathrm{kg}$, and the profit from the conversion of biomass into heat, electricity and liquid fuel is in the proportions: $1: 3: 9$ [23, 24]. Considering the types of pyrolysis, two types of liquid fuels are distinguished. The high-efficiency rapid pyrolysis process produces biofuels that are $85 \%$ by weight. Their viscosity is low, they mix with water to $35-50 \%$ of the moisture content. They are susceptible to temperature, less stable, they can polymerize. They are suitable for burning in boilers, furnaces and engines. The second type is biofuels formed as a result of typical or slow pyrolysis. Their performance is less than $20 \%$ by weight [25]. In addition to pyrolysis, we distinguish processes such as: cracking, catalytic cracking, hydrocracking in the presence of hydrogen. In the case of cracking processes, their main products are fuel fractions, gas hydrocarbons, and liquid hydrocarbon blends boiling at $350-360^{\circ} \mathrm{C}$ (petrol and light diesel fuels) and cokestable solid carbonaceous solids [26]. In the case of hydrocracking, catalysts and hydrogen are used. They are designed to crack polymer chains and hydrogenate olefins. The products obtained in this way are of good quality. The disadvantage, however, is the high costs of such investments. The determination of suitable and effective cracking reactors is also a big challenge [27].

\section{ALTERNATIVE PETROCHEMICAL GASIFICATION}

Polymeric materials constitute much more "ecological" fuel than a number of fuels

fossil, containing heavy metals, toxic and even radioactive elements. The basis of gasification can be municipal waste together with the waste contained therein made of polymer materials previously subjected to the process separating only the most valuable ones ingredients: PET, polycarbonates, poly (methyl methacrylate).

Gas purification from the gasification process, for energy and chemical purposes processing, is not a technical or economic problem for modern technology. The nuisance of such treatment is comparable or smaller than the nuisance of exhaust gas treatment from the incineration of municipal waste 
or biomass. Many disadvantages processes running under combustion conditions is in the case of gasification (catalytic) - inhibited due to the presence of significant products in the stream amount of hydrogen. Solid fuel gasification is high temperature $\left(600-1400^{\circ} \mathrm{C}\right)$, the process of converting them to fuels gaseous under the influence of a gasifying agent: oxygen, air, steam, carbon dioxide or mixtures thereof. Gasification products are: syngas, small amounts of methane, $\mathrm{CO}_{2}, \mathrm{H}_{2} \mathrm{O}, \mathrm{N}_{2}$ and, depending on type of charge used, negligible amounts of $\mathrm{H}_{2} \mathrm{~S}$, NOx and oeladium quantities of $\mathrm{NH}_{3}, \mathrm{HCl}, \mathrm{HCN}$ in the condensed phase there are flammable products - tar and carbonizate. Tar contains aromatic hydrocarbons (mainly toluene, naphthalene and phenol) and polyaromatic. A solid product gasification is mineral ash. With increasing temperature the proportion of tar decreases significantly in gasification products, its composition also changes -benzene becomes its main component (it constitutes over $50 \%$ aromatic fraction) $[28,29,30]$.

Gasification is beneficial for energy production processes from mixed feeds, this results in more efficient combustion and the resulting gas is a homogeneous fuel and can be used in energychemical systems. Polyolefins, obtained from the pyrolysis of a wide fraction of products FischerTropsch and methanol synthesis, other monomers obtained in the methanol cascade processing, allow the re-production of polymers and polymer materials using processes in the mass balance waste of polymer materials contained in charge in the gasification process. Polymeric petrochemical materials are dependent on a shrinking mineral resource base. Considering the calorific value of plastic waste, it should be stated that it is large and comparable with the energy input of processing and the calorific value of energy carriers of refinery origin. These factors affect the perception of waste management of polymer materials.

The strategy should include the recovery of what is valuable and at the same time easy to recover from the recovery of waste and energy by burning or gasifying cheap and difficult to isolate waste. The combustion preferably takes place by burning the materials together with coal, biomass and sewage sludge. The gasification and co-gasification process allows to obtain energy products such as high calorific fuels and synthesis gas for alternative petrochemical products. Obtaining olefins from the pyrolysis of a wide fraction of products

Fischer-Tropsch synthesis and methanol conversion (MTO, MTP), obtaining other monomers from them, finally, their polymerization is the implementation of recycling of the second generation of raw materials. It is recycling that allows in the conditions of autothermal processes to obtain raw materials and new polymer materials from waste. This solution, thanks product transport possibilities (liquid hydrocarbons from F-T, MTO, MTP vs. technological heat from the incineration plant), increases the impact area, further increasing

added value of raw material recycling technology (shortening the payback period). Energy recovery can be carried out at any scale. The directions and scale of product processing depend on profitability, logistics, the possibility of further use of products and connections resulting from production [31].

\section{CONCLUSIONS}

The management of plastic waste is still a current problem related to economics, industry, and above all to environmental protection. There are several options for managing plastic waste, all of these processes are constantly improved so that plastics can be recycled that will have good mechanical quality and durability. The risks are still plastics made of various polymer materials, and the challenge for the world of science is still to create the possibility of separating such materials into individual components. When materials can not be subjected to a biodegradation process, energy recycling and energy recovery is an alternative to getting the benefits of plastics processing. The work of scientists focuses on better understanding of the process of pyrolysis and modification of polymer chain breakdown with the use of catalysts, taking into account the smallest possible defects that would have a negative impact on the environment. Scientists research also focuses on the possibilities of recycling particularly troublesome materials such as multilayer packaging and the best possible use of materials. Among the recycling methods, the most popular are: mechanical recycling, chemical recycling, pyrolysis and energy recovery. Researchers are still looking for new possibilities for the development of the biodegradation process using microbial activity.

\section{References}

1. Bodzay, B.; Bánhegyi, G., Polymer waste: controlled breakdown or recycling?. Int. J. Des. Sci. Tech., 22(2), 2016

2. Geyer, R., Jambeck, J. R. \& Law, K. L. Production, use, and fate of all plastics ever made. Sci. Adv. 3, e1700782, 2017

3. Lebreton, L. C. M. et al. River plastic emissions to the world's oceans. Nat. Commun. 8, 15611, 2017

4. Rydzkowski T., Teoretyczne i doświadczalne podstawy efektywnego wytłaczania ślimakowo-tarczowego w recyklingu materiałów i kompozytów polimerowych., Monografia, Wydawnictwo Uczelniane Politechniki Koszalińskiej, Koszalin 2012

5. Rydzkowski T., Recykling odpadowych tworzyw polimerowych., Recykling, 5, s. 25-25, 2009

6. Guide to Energy Efficiency Opportunities in the Canadian Plastics Processing Industry, Natural Resources Canada's Office of Energy Efficiency, Canada, 13, 33, 2007 
7. James D. H., Castor W. M., Styrene Ullmann's Encyclopedia of industrial Chemistry, Wiley-VCH, 2005.

8. https://www.plasticseurope.org/pl/resources/publications /1999-tworzywa-fakty-2019

9. Lipinsky E., Wesson R., Characterization of the Top 12 U.S. Commodity Polymers. A Pacific Northwest National Laboratory report submitted to the U.S. Department of Energy, Biological and Chemical Technology Research Program, 1995

10. 10.https://www.plasticseurope.org/pl/focusareas/circular-economy/zero-plastics-landfill/recyclingand-energy-recovery

11. Nature Comunnications 9:2157 DOI: $10.1038 / \mathrm{s} 41467-018$ 04565-2 | www.nature.com/naturecommunications, 2018

12. Anuar Sharuddin S., Abnisa F., Wan Daud W., Aroua M., A review on pyrolysis of plastic wastes. Energy Convers Manage, p. 115:308-26, 2016

13. Abnisa F., Daud W., Sahu J., Pyrolysis of mixtures of palm shell and polystyrene: an optional method to produce a high-grade of pyrolysis oil. Environ Prog Sustain Energy, 33(3), p. 1026-33, 2014

14. Pinto F., Costa P., Gulyurtlu I., Cabrita I., Pyrolysis of plastic wastes. 1. Effect of plastic waste composition on product yield. J Anal Appl Pyrolysis, 51, p. 39-55, 1998

15. Matsumoto S, Grause G, Kameda T, Yoshioka T. Pyrolysis of mixed plastics in the fluidized bed using hard burnt lime as bed material. The 5th ISFR, Chengdu, China; 2009

16. Miandad R., Barakat M., et all, Effect of plastic waste types on pyrolysis liquid oil. Int Biodeterior Biodegradation 2016.

17. Kirby M., et all, The role of thermo-catalytic reforming for energy recovery from food and drink supply chain wastes., Energy Procedia 123, p. 15-21, 2017

18. Neumann, J., et all, The conversion of anaerobic digestion waste into biofuels via a novel ThermoCatalytic Reforming process. Waste Manage, 47, p. 141148,2016

19. Bridgwater A., et all, An overview of fast pyrolysis of biomass, Organic Geochemistry, 30, p. 1479-1493, 1999

20. Bridgewater A., Biomass fast pyrolysis, Thermal Science, 8, p. 21-50, 2004

21. Mohan D., Pittman C., Steele P., Pyrolysis of wood/biomass for bio-oil: a critical review, Energy \& Fuels, 20, p. 848-889, 2006

22. Bridgwater A., Review of fast pyrolysis of biomass and product upgrading, Biomass and Bioenergy, 38, p. 68-94, 2012

23. Ryms M., et all, Pyrolysis process of whole waste tires as a biomass energy recycling., Ecol Chem Eng S. 20(1), p. 93-107, 2013

24. Pilawski M, Grzybek A, Rogulska M. Ecol and Technol., $8(2)$, p. $48-53,2000$

25. Ryms M., et all, Pyrolysis process of whole waste tires as a biomass energy recycling., Ecol Chem Eng S. 20(1), p. 93-107, 2013

26. Walendziewski J., Continuous flow cracking of waste plastics., Fuel Processing Technology 86, p. 1265 1278, 2005

27. Brems A., et al., Polymeric Cracking of Waste Polyethylene-Terephthalate to Chemicals and Energy, International Journal of Sustainable Engineering, 3, 4, p. 232-245, 2010

28. Kijeński J., Kijeńska M., Migdał A., Współzgazowanie strategiczny kierunek zagospodarowania odpadów tworzyw polimerowych., Polimery, 59, 5, 2014

29. SVZ Schwarze Pumpe gasifier coal and wastes for CHP”, Modern Power Systems, 9, 1996

30. Babu S.P.:Workshop No. 1: Perspectives on Biomass Gasification, IEA Bioenergy Agreement, Task 33: Thermal Gasification of Biomass, May 2006.
31. Kijeński J., Rejewski P.: „Synteza produktów chemicznych z gazu ze zgazowania węgla”, w „Studium koncepcyjne wybranych technologii perspektywicznych procesów i produktów konwersji węgla - osiągnięcia i kierunki badawczo- rozwojowe, tom 2: Synteza produktów chemicznych" (red. Kijeński J., Ściążko M.), Wydawnictwo Instytutu Chemicznej Przeróbki Węgla

\section{Biographical notes}

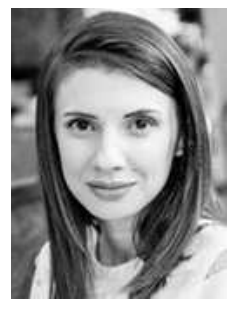

Jolanta Wróblewska-Krepsztul since 2016 is a participant of doctoral studies at the Faculty of Mechanical Engineering of the Koszalin University of Technology and a $\mathrm{PhD}$ student at the Department of Equipment and Processes of the Food Industry. As part of her doctoral dissertation, she deals with the issue of the impact of screw-disc extrusion process parameters on the properties and degradation of polymer-wood composites. Her area of scientific interest includes recycling, biodegradation of polymer materials, biopolymers and polymer-wood composites.

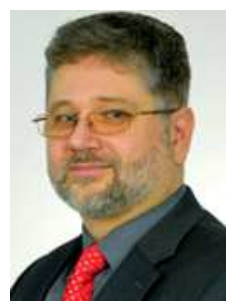

Tomasz Rydzkowski is a scientist and teacher at the Faculty of Mechanical Engineering of the Koszalin University of Technology. In 2001 he obtained the degree of doctor of technical sciences in the discipline of Machine Construction and Exploitation and in 2014 he obtained the degree of habilitated doctor of technical sciences in the same discipline. In his scientific activity, he mainly deals with the processing and recycling of polymer materials and composites, as well as food processing engineering and technology, in particular packaging materials and systems. $\mathrm{He}$ was the promoter of over 100 master's and engineering diploma theses. He prepared reviews in doctoral and habilitation proceedings. He carried out research projects of the State Committee for Scientific Research and Ministry of Science and Higher Education, is a court expert, performs numerous expert functions, cooperates intensively with the economic environment. Passions and hobbies: travel, photography and sailing. 